\title{
Conception Profile of Students in Class XI.1 Science on Chemical Equilibrium Materials with Pogil Learning Model to Reduce Misconception
}

\author{
Ifsantin Silma Rizqiyah \\ Post Graduate Program \\ Science Education \\ Universitas Negeri Surabaya, Indonesia
}

\author{
Suyatno Sutoyo \\ Professor of Chemistry \\ Lecture of Postgraduate Program \\ Universitas Negeri Surabaya \\ Indonesia
}

\author{
Leny Yuanita \\ Professor of Chemistry \\ Lecture of Postgraduate Program \\ Universitas Negeri Surabaya \\ Indonesia
}

\begin{abstract}
Misconceptions can be caused due to a person's low understanding of a concept, as a result it will influence a person in understanding and connecting between existing knowledge principles. Several studies were conducted to find out what strategies can be used to reduce student misconceptions, especially in chemistry lessons. The purpose of this study is to describe the concept profile of students after using the POGIL learning model to reduce student misconceptions. The subjects in this study were students of class XI.1 Science who had received chemistry learning about chemical equilibrium. The data collection instruments used included observation sheets of learning activities and tests of understanding the concept of multiple choice reasoned and accompanied by the level of confidence of students (three tier). Data analysis was carried out descriptively with a three tier diagnostic test. The results of the analysis of the student's misconception profile that have been obtained are then mapped individually and personally. The results showed that the profile of students 'conception after learning using the POGIL learning model, most of the students' conceptions experienced positive changes with the translation of students with initial misconceptions, not knowing the concept changed to knowing the concept, and students who remained on the profile knew the concept but still there are students who are still in the misconception profile. Through the results of this study, it is hoped that it will be useful for education practitioners in choosing alternative learning strategies in delivering chemical equilibrium subject matter and as a reference for overcoming students who are still experiencing misconceptions.
\end{abstract}

Keywords:- Profile, Conceptual Understanding, Misconceptions, Chemical Equilibrium.

\section{INTRODUCTION}

Low conceptual understanding can be caused by the occurrence of misconceptions, if this happens students have difficulty understanding and connecting the principles and concepts of chemistry taught with natural events in everyday life. Concept understanding is part of human cognitive and is an important factor in learning. In chemistry learning requires a lot of understanding of concepts, so that students can solve relevant problems with concepts that are in accordance with the understanding of experts [1].

Understanding the concept of a chemistry learning material requires a fairly high generalization and abstraction ability, so that students' understanding of concepts is still weak [2]. The learning difficulties of students can lead to low concept mastery [3]. Misconceptions can cause learning difficulties for students so that student learning outcomes are low [4]. Concept errors occur when students use initial knowledge as a basis for evaluating newly acquired information.

Misconceptions still occur even though students have been introduced to the correct concept, but there is still a chance to return to the wrong initial conception of students (misconception) [5]. If there are still students who experience misconceptions, where these students have mixed and unclear understandings by displaying the incoherence of information if it is related to the desired concept [6]. Students who have good academic abilities can have low self-confidence, so the results shown are unsatisfactory because of fears that they will be wrong, causing misconceptions to recur [7].

If the learning that is carried out is meaningful for students, the misconceptions that occur in students can be corrected properly and the material that has been studied will enter into long-term memory and have good retention in the memory of students. Meaningful learning can be realized with a constructivist approach. One of the learning models that can be used as an alternative for teachers in 
teaching and learning activities that can reduce misconceptions is a guided inquiry-based learning model in the form of Process Oriented Guided Inquiry Learning (POGIL) [8].

POGIL learning model has specific learning steps and structures and is consistent with leading to the expected goals of students using skills for the learning process [8]. The skills used by students are able to change their knowledge construction and form new concepts that are in accordance with scientific concepts [9]. The classical load of misconceptions using the Wilcoxon test shows that there are significant differences in misconceptions between before and after remediation learning with the POGIL learning model [10], so that the POGIL strategy is able to reduce student misconceptions.

Based on this, it is necessary to carry out further research to find out whether the POGIL learning model can be used as an alternative to reduce misconceptions in chemistry lessons, especially on chemical equilibrium material. Through the results of this study, it is hoped that it will be useful for education practitioners in choosing alternative learning strategies in delivering chemical equilibrium subject matter and as a reference for overcoming students who are still experiencing misconceptions.

\section{METHOD}

\section{A. Research design}

This study used a pretest posttest research design [11]. Pre-experimental research in the form of experiments conducted in only one group, without any comparison group. The research design is shown in Table 1.

\begin{tabular}{|c|c|c|}
\hline Pretest & Treatment & Posttest \\
\hline $\mathrm{O}_{1}$ & $\mathrm{X}_{1}$ & $\mathrm{O}_{2}$ \\
\hline
\end{tabular}

Table 1:- Research design

Information:

$\mathrm{O}_{1} \quad$ : Pretest (pre-test before learning POGIL and after receiving lessons from the teacher on chemical equilibrium material).

X1 : The application of POGIL learning to chemical equilibrium material

$\mathrm{O}_{2} \quad$ : Post Test (the final test after POGIL learning on chemical equilibrium material).

\section{B. Research procedure}

The initial activity was carried out by conducting a pretest on students to find out the understanding of the initial concept whether it was a misconception or not. After the student misconceptions data were obtained, the POGIL learning model was applied with a three-tier assessment to reduce misconceptions that occurred in students. After being given this treatment, a posttest will be carried out to find out the final concept of students after the learning process and to analyze the shift in students' misconceptions between before and after the application of the POGIL learning model and student learning outcomes.

\section{Partisipant}

The subjects of this study were 19 students of class XI.1 Science at Al-Furqon Senior High School in the 2019/2020 school year as many as 19 students who had learned chemical equilibrium material.

\section{Research data collection instruments and its techniques}

Student misconceptions data on chemical equilibrium material through the application of the POGIL learning model were obtained through several instruments and data collection techniques which were explained as in Table 2.

\begin{tabular}{|c|c|c|}
\hline No. & $\begin{array}{c}\text { Research data } \\
\text { collection techniques }\end{array}$ & $\begin{array}{c}\text { Research data collection } \\
\text { Instrument }\end{array}$ \\
\hline 1 & Observation & $\begin{array}{c}\text { Observation sheet for the } \\
\text { implementation of the stages } \\
\text { of the POGIL learning } \\
\text { model }\end{array}$ \\
\hline 2. & Test & $\begin{array}{c}\text { A concept understanding test } \\
\text { consisting of 5 multiple } \\
\text { choice test questions with } \\
\text { reason and the students' level } \\
\text { of confidence (three tier) }\end{array}$ \\
\hline
\end{tabular}

Table 2:- Pair of research data collection techniques and its instruments

\section{E. Data Analysis \\ > Concept Understanding Profile Analysis}

Concept understanding data produces a profile of students' misconceptions. The conceptual understanding data obtained were then analyzed descriptively using a concept understanding test in the form of a three tier diagnostic test. Consists of 3 levels which include content tier, reason tier, confidence tier to measure the degree of confidence of students in determining the answers and reasons selected. The results of the level of concept mastery are grouped in Table 3. 


\begin{tabular}{|c|c|c|c|c|}
\hline \multirow{2}{*}{$\begin{array}{c}\text { First Tier-content } \\
\text { tier (The Answer) }\end{array}$} & $\begin{array}{c}\text { Second Tier - } \\
\text { reason tier (The } \\
\text { Reason) }\end{array}$ & $\begin{array}{c}\text { Third Tier - confidence tier } \\
\text { (the confidence) }\end{array}$ & Category \\
\hline True & True & Confident & Know the Concept \\
\hline True & True & Not Confident & Don't know the concept (Lucky \\
\hline True & False & Not Confident & TTK 0 \\
\hline False & True & Not Confident & Don't know the concept & TTK 1 \\
\hline False & False & Not Confident & Don't know the concept & TTK 2 \\
\hline True & False & Confident & Misconception (false positive) & MK 1 \\
\hline False & True & Confident & Misconception (false negative) & MK 2 \\
\hline False & False & Confident & Misconception & MK 3 \\
\hline
\end{tabular}

Table 3:- Data of Concept Mastery Level Results Based on Three Tier Diagnostic Test.

\section{Analysis of Change in Students' Conceptions}

Changes in the conceptions of students obtained from the test results were analyzed by statistical methods used to analyze data that would produce general conclusions. The type of statistical test used is Wilcoxon's Signed Rank Test with the aim of testing two test samples.

\section{Conceptual Mapping Analysis}

Student misconception profile data that has been obtained are then mapped individually and personally. This mapping was carried out before and after the implementation of the POGIL learning model. The results obtained will then be grouped based on changes in conception as in Table 4.

\begin{tabular}{|c|c|}
\hline Category & Change Category \\
\hline \multirow{3}{*}{ TK } & Know the Concept (TK) \\
\cline { 2 - 2 } & Don't Know the Concept (TTK) \\
\cline { 2 - 2 } & Kisconception (MK) \\
\cline { 2 - 2 } TTK & Know the Concept (TK) \\
\cline { 2 - 2 } & Don't Know the Concept (TTK) \\
\hline \multirow{3}{*}{ MK } & Kisconception (MK) \\
\cline { 2 - 2 } & Don't Know the Concept (TK) \\
\cline { 2 - 2 } & Misconception (MK) \\
\hline
\end{tabular}

Table 4:- Mapping Categories of Conception Change

\section{RESULT AND DISCUSSION}

\section{* Students' Conception Profile}

- Students' Conception Profile Before Implementation of POGIL Learning Model

The conception profile of students can be seen through the results of the pretest and posttest. The pretest is carried out before students get learning by chemistry subject teachers on chemical equilibrium material. The posttest is carried out after students get the POGIL learning model. The identification of the overall profile of the conception of this student aims to determine the total percentage of students who know concepts, do not know concepts and misconceptions. The following is a profile of the overall conceptions of students before the implementation of the POGIL learning model which can be seen through the pretest results shown in Table 5. 
ISSN No:-2456-2165

\begin{tabular}{|c|c|c|c|c|}
\hline \multirow[b]{2}{*}{ No. } & \multirow[b]{2}{*}{ Concept } & \multicolumn{3}{|c|}{ Percentage of Students' Conception Profile } \\
\hline & & $\begin{array}{l}\text { Know the Concept } \\
\text { (TK) }\end{array}$ & $\begin{array}{l}\text { Don't Know the } \\
\text { Concept (TTK) }\end{array}$ & $\begin{array}{l}\text { Misconceptio } \\
\text { n (MK) }\end{array}$ \\
\hline 1 & \multirow{2}{*}{ Equilibrium reaction } & 44,44 & 27,78 & 27,78 \\
\hline 2 & & 50 & 22,22 & 22,22 \\
\hline 3 & \multirow{2}{*}{$\begin{array}{l}\text { Determines and calculates the equilibrium constant } \\
\text { based on concentration }\end{array}$} & 55,55 & 44,44 & 0 \\
\hline 4 & & 44,44 & 38,87 & 16,66 \\
\hline 5 & Calculating the value of $\mathrm{Kc}$ & 27,77 & 0 & 72,22 \\
\hline 6 & Calculating the value of $\mathrm{Kp}$ & 38,88 & 50 & 11,11 \\
\hline 7 & \multirow{3}{*}{ Degree of dissociation } & 61,11 & 27,77 & 11,11 \\
\hline 8 & & 27,77 & 55,55 & 16,66 \\
\hline 9 & & 38,8 & 49,99 & 11,11 \\
\hline 10 & \multirow{2}{*}{ Equilibrium reactions based on concentration } & 16,66 & 61,1 & 22,21 \\
\hline 11 & & 11,11 & 66,66 & 22,22 \\
\hline 12 & \multirow{2}{*}{ Equilibrium reaction based on pressure } & 16,66 & 44,43 & 38,88 \\
\hline 13 & & 0 & 61,1 & 38,88 \\
\hline 14 & Equilibrium reaction based on volume & 53,5 & 55,55 & 38,8 \\
\hline 15 & \multirow{2}{*}{ Equilibrium reactions in industry } & 5,55 & 49,99 & 44,43 \\
\hline 16 & & 5,55 & 61,1 & 33,33 \\
\hline 17 & \multirow{3}{*}{ Equilibrium reaction based on temperature } & 5,55 & 66,65 & 27,77 \\
\hline 18 & & 5,55 & 61,09 & 33,33 \\
\hline 19 & & 16,66 & 72,16 & 11,11 \\
\hline 20 & \multirow{2}{*}{ Reaction questionnaire (Q) } & 5,55 & 66,64 & 27,77 \\
\hline 21 & & 5,55 & 66,66 & 27,77 \\
\hline 22 & The relationship between $\mathrm{Kc}$ and $\mathrm{Kp}$ & 5,55 & 66,65 & 27,77 \\
\hline 23 & Equilibrium reaction based on volume & 5,55 & 61,08 & 33,33 \\
\hline & Overall Average & 22,46 & 51,69 & 26,09 \\
\hline
\end{tabular}

Table 5:- The Percentage of Students' Conception Profiles Before the Implementation of the POGIL Learning Model in Class XI.1.

Comparison of the overall percentage of conceptions of XI 1 students who know the concept (TK), do not know the concept (TTK) and misconceptions (MK) before treatment can also be visualized in the form of a histogram, it can be presented in Figure 1.

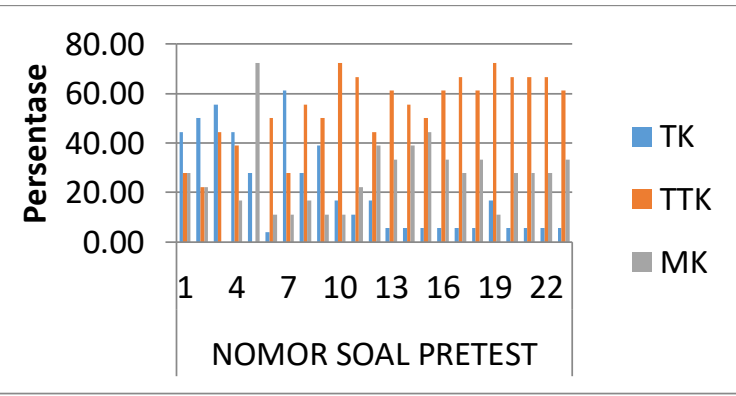

Fig 1:- Percentage Histogram of Class XI 1 Students who Know Concepts, Don't Know Concepts and Misconceptions in Thermochemical Materials Before the Implementation of the POGIL learning model.
Based on the data in Table 5 and Figure 5, the results of the analysis are as follows: Concepts that are understood by students, almost every item of question shows that the overall percentage is in the category of not knowing concepts and misconceptions. The understanding of students in the concept know category seems not optimal, it is shown from the difference in the percentage achieved in each concept which is reversed by several items that get high and varied percentage values. The percentage of not knowing the concept and misconceptions is greater than the percentage knowing the concept.

Students' Conception Profile After Implementation of POGIL Learning Model

The conception profile of class XI.1 students after the implementation of the POGIL learning model can be seen through the posttest results shown in Table 6 . 
ISSN No:-2456-2165

\begin{tabular}{|c|c|c|c|c|}
\hline \multirow[b]{2}{*}{ No. } & \multirow[b]{2}{*}{ Concept } & \multicolumn{3}{|c|}{$\begin{array}{ll}\text { Percentage of Students' Conception Profile } \\
\end{array}$} \\
\hline & & $\begin{array}{l}\text { Know the Concept } \\
\text { (TK) }\end{array}$ & $\begin{array}{l}\text { Don't Know the } \\
\text { Concept (TTK) }\end{array}$ & Misconception (MK) \\
\hline 1 & \multirow{2}{*}{ Equilibrium reaction } & 94,4 & 0 & 5,56 \\
\hline 2 & & 100 & 0 & 0 \\
\hline 3 & \multirow{2}{*}{$\begin{array}{l}\text { Determines and calculates the } \\
\text { equilibrium constant based on } \\
\text { concentration }\end{array}$} & 77,78 & 16,67 & 5,56 \\
\hline 4 & & 100 & 0 & 0 \\
\hline 5 & Calculating the value of $\mathrm{Kc}$ & 94,4 & 0 & 5,56 \\
\hline 6 & Calculating the value of $\mathrm{Kp}$ & 83,3 & 5,56 & 11,11 \\
\hline 7 & \multirow{3}{*}{ Degree of dissociation } & 94,4 & 0 & 5,56 \\
\hline 8 & & 100 & 0 & 0 \\
\hline 9 & & 83,33 & 5,56 & 11,11 \\
\hline 10 & \multirow{2}{*}{$\begin{array}{l}\text { Equilibrium reactions based on } \\
\text { concentration }\end{array}$} & 94,44 & 0 & 5,56 \\
\hline 11 & & 77,78 & 0 & 22,22 \\
\hline 12 & \multirow{2}{*}{$\begin{array}{c}\text { Equilibrium reaction based on } \\
\text { pressure }\end{array}$} & 94,4 & 0 & 5,56 \\
\hline 13 & & 83,3 & 5,56 & 11,11 \\
\hline 14 & $\begin{array}{c}\text { Equilibrium reaction based on } \\
\text { volume }\end{array}$ & 83,33 & 5,56 & 11,11 \\
\hline 15 & \multirow{2}{*}{$\begin{array}{c}\text { Equilibrium reactions in } \\
\text { industry }\end{array}$} & 88,89 & 5,56 & 5,56 \\
\hline 16 & & 94,44 & 5,56 & 0 \\
\hline 17 & \multirow{3}{*}{$\begin{array}{l}\text { Equilibrium reaction based on } \\
\text { temperature }\end{array}$} & 72,2 & 5,56 & 22,22 \\
\hline 18 & & 88,89 & 0 & 11,11 \\
\hline 19 & & 94,44 & 5,56 & 0 \\
\hline 20 & \multirow{2}{*}{ Reaction questionnaire (Q) } & 94,44 & 0 & 5,56 \\
\hline 21 & & 72,22 & 0 & 27,78 \\
\hline 22 & $\begin{array}{l}\text { The relationship between Kc } \\
\text { and Kp }\end{array}$ & 94,4 & 0 & 5,56 \\
\hline 23 & $\begin{array}{l}\text { Equilibrium reaction based on } \\
\text { volume }\end{array}$ & 83,33 & 11,11 & 5,56 \\
\hline & Overall Average & 88,89 & 3,14 & 7,97 \\
\hline
\end{tabular}

Table 6:- Percentage of Students' Conception Profiles after the Implementation of the POGIL learning model in Class XI.1

Based on Table 6, it shows that after the implementation of the POGIL learning model students from class XI 1 know the concept, but there are still some students who do not know concepts and misconceptions. Comparison of the percentage of conceptions of class XI 1 students who know the concept (TK), do not know the concept (TTK) and misconception (MK) after treatment can also be visualized in the form of a histogram, it can be presented in Figure 2.

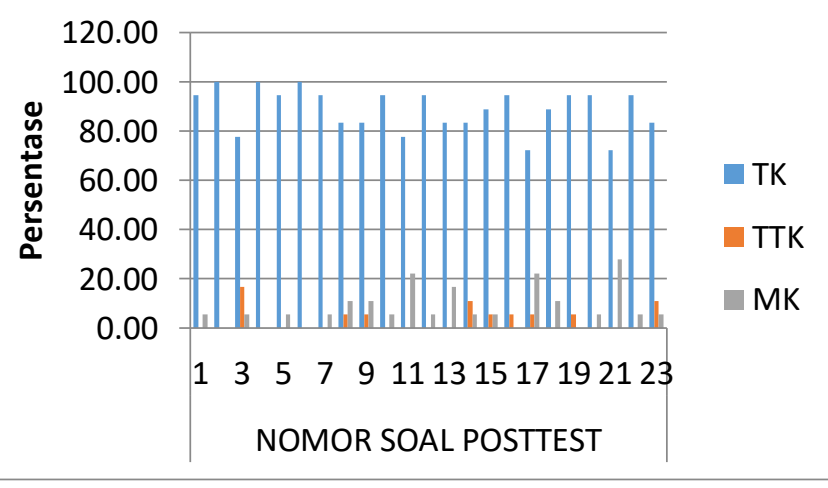

Fig 2:- The Percentage Histogram of Class XI.1 Students Who Know the Concept, Don't Know the Concept and the Misconceptions in the Material of Chemical equilibrium after the implementation of the POGIL learning model
Based on the data in Table 6 and Figure 2, the results of the analysis are given as follows: most concepts are understood by students by knowing the concepts. Almost every item of the question shows that the condition of knowing the concept has a fairly large percentage, almost every item still shows the percentage of not knowing the concept and misconception even though in a small number. This shows that students' understanding is more likely to know concepts than not to know concepts and misconceptions.

The results on the final test show that the students understanding has changed when compared to the initial conditions. The initial test was in the form of a pretest class XI.1 the tendency of each concept to be more in the condition of not knowing the concept and misconceptions, but the final test showed that the students' understanding was more towards the condition of knowing the concept.

\section{Changes in students' conceptions}

Conception changes were tested using the Wilcoxon ranked sign test, to show concept changes that occurred in students as a result of treatment during the implementation of the POGIL learning model in learning. Before carrying out the Wilcoxon ranked sign test. 
ISSN No:-2456-2165

- Research hypothesis:

Ho: there is no difference in learning outcomes in the pretest and posttest

H1: there is no difference between pretest and posttest learning outcomes

- Basic decision making:

If Asyimp. Sig. <0.05, then H1 is accepted

If Asyimp. Sig. $>0.05$ then H1 is rejected, accepting Ho

\begin{tabular}{|c|c|c|}
\hline \multicolumn{3}{|c|}{ Test Statistics $^{\text {a }}$} \\
\hline & $\begin{array}{c}\text { POSTTEST1 - } \\
\text { PRETEST1 }\end{array}$ & $\begin{array}{c}\text { POSTTEST2 - } \\
\text { PRETEST2 }\end{array}$ \\
\hline$Z$ & $-3.732^{\mathrm{b}}$ & $-3.725^{\mathrm{b}}$ \\
\hline Asymp. Sig. (2-tailed) & .000 & .000 \\
\hline \multicolumn{2}{|c|}{ a. Wilcoxon Signed Ranks Test } \\
\hline \multicolumn{2}{|c|}{ b. Based on negative ranks. } \\
\hline
\end{tabular}

Based on the output of the statistical test above, it shows that the Asymp. Sig. (2-tailed) for all pretest and posttest data for all trial classes $<0.05$, so it can be concluded that $\mathrm{H} 1$ is accepted, meaning that there is a difference in pretest and posttest scores. Changes in the conceptions of students will be shown in Table 7.

\begin{tabular}{|c|c|c|c|c|c|c|c|c|c|}
\hline \multirow{2}{*}{ Concept } & \multicolumn{3}{|c|}{ Know the Concept (TK) } & \multicolumn{3}{|c|}{$\begin{array}{l}\text { Don't Know the Concept } \\
\text { (TTK) }\end{array}$} & \multicolumn{3}{|c|}{ Misconception (MK) } \\
\hline & B & $\mathbf{A}$ & Inf. & B & $\mathbf{A}$ & Inf. & B & $\mathbf{A}$ & Inf. \\
\hline \multirow{2}{*}{ Equilibrium reaction } & 8 & 17 & Increase & 5 & 0 & Reduce & 5 & 1 & Reduce \\
\hline & 9 & 17 & Increase & 4 & 0 & Reduce & 5 & 1 & Reduce \\
\hline \multirow{2}{*}{$\begin{array}{l}\text { Determines and } \\
\text { calculates the } \\
\text { equilibrium constant } \\
\text { based on concentration }\end{array}$} & 10 & 14 & Increase & 8 & 3 & Reduce & 0 & 1 & Reduce \\
\hline & 8 & 18 & Increase & 7 & 0 & Reduce & 3 & 0 & Reduce \\
\hline $\begin{array}{l}\text { Calculating the value of } \\
\text { Kc }\end{array}$ & 5 & 15 & Increase & 0 & 1 & Increase & 13 & 2 & Reduce \\
\hline $\begin{array}{l}\text { Calculating the value of } \\
\mathrm{Kp}\end{array}$ & 7 & 15 & Increase & 9 & 0 & Reduce & 2 & 3 & Increase \\
\hline \multirow{3}{*}{ Degree of dissociation } & 11 & 17 & Increase & 5 & 0 & Reduce & 2 & 1 & Reduce \\
\hline & 5 & 15 & Increase & 10 & 1 & Reduce & 3 & 2 & Reduce \\
\hline & 7 & 15 & Increase & 9 & 1 & Reduce & 2 & 2 & Still \\
\hline \multirow{2}{*}{$\begin{array}{l}\text { Equilibrium reactions } \\
\text { based on concentration }\end{array}$} & 3 & 14 & Increase & 13 & 0 & Reduce & 2 & 4 & Increase \\
\hline & 2 & 17 & Increase & 12 & 0 & Reduce & 4 & 1 & Reduce \\
\hline \multirow{2}{*}{$\begin{array}{l}\text { Equilibrium reaction } \\
\text { based on pressure }\end{array}$} & 3 & 17 & Increase & 8 & 0 & Reduce & 7 & 1 & Reduce \\
\hline & 1 & 18 & Increase & 11 & 0 & Reduce & 6 & 0 & Reduce \\
\hline $\begin{array}{l}\text { Equilibrium reaction } \\
\text { based on volume }\end{array}$ & 1 & 15 & Increase & 10 & 2 & Reduce & 7 & 1 & Reduce \\
\hline \multirow{2}{*}{$\begin{array}{c}\text { Equilibrium reactions in } \\
\text { industry }\end{array}$} & 1 & 16 & Increase & 9 & 1 & Reduce & 8 & 1 & Reduce \\
\hline & 1 & 17 & Increase & 11 & 1 & Reduce & 6 & 0 & Reduce \\
\hline \multirow{3}{*}{$\begin{array}{l}\text { Equilibrium reaction } \\
\text { based on temperature }\end{array}$} & 1 & 13 & Increase & 12 & 1 & Reduce & 5 & 4 & Reduce \\
\hline & 1 & 16 & Increase & 11 & 0 & Reduce & 6 & 2 & Reduce \\
\hline & 3 & 17 & Increase & 13 & 1 & Reduce & 2 & 0 & Reduce \\
\hline \multirow{2}{*}{$\begin{array}{l}\text { Reaction questionnaire } \\
\text { (Q) }\end{array}$} & 1 & 17 & Increase & 12 & 0 & Reduce & 5 & 1 & Reduce \\
\hline & 1 & 13 & Increase & 12 & 0 & Reduce & 5 & 5 & Still \\
\hline $\begin{array}{c}\text { The relationship } \\
\text { between } \mathrm{Kc} \text { and } \mathrm{Kp}\end{array}$ & 1 & 18 & Increase & 12 & 0 & Reduce & 5 & 0 & Reduce \\
\hline $\begin{array}{c}\text { Equilibrium reaction } \\
\text { based on volume }\end{array}$ & 1 & 15 & Increase & 11 & 2 & Reduce & 6 & 1 & Reduce \\
\hline
\end{tabular}

Table 7:- Changes in the Students' conception in Class XI.1

Based on Table 7, the results of the analysis of students know the concepts in each concept increase after being given learning with the POGIL learning model. The condition of students did not know the concept of the average decreased, but the concept of calculating the value of Kc increased. The condition of students in the misconception category was reduced, except for the concept of calculating the value of Kp increased and the concept of the degree of dissociation was fixed. 
Some students who initially had misconceptions, at the end of the lesson, still experienced misconceptions. This is in accordance with the opinion of Suparno and Clement who reveal that misconceptions are very difficult to change [12]; [13]. Misconceptions cannot be changed just by presenting new information [14]. Clement also revealed that misconceptions cannot be changed only by classical teaching methods or lectures [12].

Students return to using the old concept to answer concept understanding questions. According to constructivist theory, this is because misconceptions are a natural thing in the process of forming knowledge by students who are learning. The teacher cannot impose "knowledge" on students. Teachers can only help students "know", if students themselves are actively involved in the learning process properly [12]. In this lesson, teachers do not provide elaboration and reinforcement at the end of the lesson because of the limited time available so that they still experience misconceptions.

\section{CONCLUSION}

The results of the study shows that the students 'conception profiles after learning using the POGIL learning model, most of the students' conceptions experienced positive changes with the explanation of students with initial conceptions of misconceptions, not knowing the concept changed to knowing the concept, and students who remained on the profile knew the concept but there are still students who are still in the misconception profile.

\section{ACKNOLEDGEMENT}

We thank you for the support of the State University of Surabaya, East Java, Indonesia. We appreciate the participation of students, teachers and parents.

\section{DECLARATION OF CONFLICT INTEREST}

The author states there is no potential conflict of interest in connection with the research, authorship and / or publication of this article.

\section{REFERENCES}

[1]. Inayah, Iin. "Studi Miskonsepsi Pembelajaran Kimia Siswa Kelas II Semester Gasal MAN Yogyakarta I Tahun Ajaran 2002/2003." Yogyakarta: IAIN Sunan Kalijaga (2003).

[2]. Nizarwati, Nizarwati, Yusuf Hartono, and Nyimas Aisyah. "Pengembangan perangkat pembelajaran berorientasi konstruktivisme untuk mengajarkan konsep perbandingan trigonometri siswa kelas $\mathrm{X}$ SMA." Jurnal Pendidikan Matematika 3.2 (2009).

[3]. TRUMPER, Ricardo. Being constructive: An alternative approach to the teaching of the energy concept--part one. International journal of science education, 1990, 12.4: 343-354.
[4]. ISTIJABATUN, Siti. Pengaruh Pengetahuan Alam terhadap Pemahaman Matapelajaran Kimia. Jurnal Inovasi Pendidikan Kimia, 2008, 2.2.

[5]. Ibrahim, Muslimin. 2012. Seri Pembelajaran Inovatif, Konsep, Miskonsepsi dan Cara Pembelajaran. Surabaya: Unipres UNESA.

[6]. Abraham. M. R., Grzybowski. E. B., Renner. J. W., \& Mark. E. A. 1992. "Understanding and Misunderstanding of Eight Grades of Five Chemistry Concept in Text Book". Journal of Research in Science Teaching. 29 (12), 105-120.

[7]. BANDURA, Albert. Perceived self-efficacy in cognitive development and functioning. Educational psychologist, 1993, 28.2: 117-148.

[8]. HANSON, David M. Instructor's guide to processoriented guided-inquiry learning. Lisle, IL: Pacific Crest, 2006.

[9]. SUPARNO, Paul. Miskonsepsi \& perubahan konsep dalam pendidikan fisika. Gramedia Widiasarana, 2013.

[10]. SULALAH BM, A. N. I. S. IMPLEMENTASI STRATEGI POGIL UNTUK MEREDUKSI MISKONSEPSI PADA MATERI STOIKIOMETRI KELAS $X$ DI SMAN 1 KANDANGAN (IMPLEMENTATION POGIL STRATEGY TO REDUCE MISCONCEPTIONS STOICIOMETRY CLASS X IN SMAN 1 KANDANGAN). UNESA Journal of Chemical Education, 2014, 3.3.

[11]. CRESWELL, John W. A concise introduction to mixed methods research. SAGE publications, 2014.

[12]. Suparno, P. (2005). MIskonsepsi dan Perubahan Konsep Dalam Pendidikan Fisika. Jakarta: Grasindo.

[13]. CLEMENT, John. Misconceptions in graphing. In: Proceedings of the ninth international conference for the psychology of mathematics education. Utrecht, The Netherlands: Utrecht University, 1985. p. 369375.

[14]. ARENDS, Dick; KILCHER, Ann. Teaching for student learning: Becoming an accomplished teacher. Routledge, 2010. 